\title{
Elevated Expression of Moesin in Muscular Dystrophies
}

\author{
Mark Pines, ${ }^{*}$ Oshrat Levi, ${ }^{*}$ Olga Genin, ${ }^{*}$ Adi Lavy, ${ }^{\dagger \dagger}$ Corrado Angelini, ${ }^{\ddagger}$ Valérie Allamand, ${ }^{\S}$ and Orna Halevy
}

\begin{abstract}
From the Institute of Animal Sciences, * Volcani Center, Bet Dagan, Israel; the Department of Animal Sciences, ${ }^{\dagger}$ the Hebrew University of Jerusalem, Rehovot, Israel; the Istituto di Ricovero e Cura a Carattere Scientifico Fondazione Ospedale S. Camillo, ${ }^{\ddagger}$ Venice, Italy; and the Research Center in Myology, ${ }^{\S}$ UPMC Univ Paris 06-Inserm Unité Mixte de Recherche en Santé 974, Centre National de la Recherche Scientifique Formation de Recherche en Evolution 3617, Institut de Myologie, Groupe Hospitalier Pitié-Salpêtrière, Paris, France
\end{abstract}

Accepted for publication November 15, 2016.

Address correspondence to Mark Pines, Ph.D., Institute of Animal Sciences, Volcani Center, PO Box 15159, HaMaccabim Rd, Rishon LeTsiyon 7528809, Israel. E-mail: mark. pines@mail.huji.ac.il.

\begin{abstract}
Fibrosis is the main complication of muscular dystrophies. We identified moesin, a member of the ezrinradixin-moesin family, in dystrophic muscles of mice representing Duchenne and congenital muscular dystrophies (DMD and CMD, respectively) and dysferlinopathy, but not in the wild type. High levels of moesin were also observed in muscle biopsy specimens from DMD, Ullrich CMD, and merosin-deficient CMD patients, all of which present high levels of fibrosis. The myofibroblasts, responsible for extracellular matrix protein synthesis, and the macrophages infiltrating the dystrophic muscles were the source of moesin. Moesin-positive cells were embedded within the fibrotic areas between the myofibers adjacent to the collagen type I fibers. Radixin was also synthesized by the myofibroblasts, whereas ezrin colocalized with the myofiber membranes. In animal models and patients' muscles, part of the moesin was in its active phosphorylated form. Inhibition of fibrosis by halofuginone, an antifibrotic agent, resulted in a major decrease in moesin levels in the muscles of DMD and CMD mice. In summary, the results of this study may pave the way for exploiting moesin as a novel target for intervention in MDs, and as part of a battery of biomarkers to evaluate treatment success in preclinical studies and clinical trials. (Am J Pathol 2017, 187: 654-664; http://dx.doi.org/10.1016/j.ajpath.2016.11.013)
\end{abstract}

Muscular dystrophies (MDs) are a heterogeneous group of genetic disorders characterized by progressive loss of muscle strength and integrity. They can be transmitted as autosomal dominant, autosomal recessive, and X-linked traits and can also arise as a result of de novo mutation. The membranes of the fibers are fragile and experience extensive damage, leading to necrosis and muscle wasting that is characterized by progressive muscle weakness and degeneration, with cycles of muscle necrosis and regeneration. All patients exhibit muscle degeneration, impaired locomotion, and, in many cases, premature death. ${ }^{1,2}$ Some forms of MD are seen in infancy or childhood [eg, Duchenne and congenital muscular dystrophies (DMD and CMD, respectively)], whereas others, such as dysferlinopathy, may not appear until middle age or later. Although the disorders differ in terms of the mutations, distribution, and extent of muscle weakness, age of onset, rate of progression, and pattern of inheritance, the unifying feature of the dystrophies is muscle histopathology, with variations in fiber size, proportion of myofibers with central nuclei, invasion of macrophages, and, ultimately, replacement of healthy tissue with fat and connective tissue. ${ }^{3}$ In some MDs, a progressive loss of muscle and its ability to function are associated with significant fibrosis that correlates with poor motor outcome. ${ }^{4}$ In DMD, the leading causes of deathrespiratory and heart failure-result from weakness in the diaphragm and myocardium, respectively, which are the tissues most affected by fibrosis. ${ }^{5,6}$ Similar to human patients, myocardium and diaphragm are the tissues most affected by fibrosis in the X-linked golden retriever ${ }^{7}$ and the $m d x$ mouse, ${ }^{8}$ both models of DMD, and their failure

\footnotetext{
Supported by Association Duchenne Israel, the Israeli Parents' Duchenne/Becker Association (M.P.); Little Steps - the Association for Children with Duchenne/Becker Muscular Disorders (M.P.); and Eurobiobank and Telethon Network of Genetic Biobank grant GUP 12007 (for the Duchenne muscular dystrophy biopsy specimens).

Disclosures: None declared.
} 
makes a major contribution to morbidity and mortality. The levels of transforming growth factor- $\beta$ (TGF- $\beta$ ), the main fibrosis effector, are higher in the muscle and plasma of MD patients. ${ }^{9-12}$ Collagen type $I$ is the major protein of the connective tissue of the dystrophic muscle, and its level correlates with muscle destruction. ${ }^{13}$ Muscle fibrosis also occurs in $\mathrm{CMD}^{14}$ and to a lesser extent in dysferlinopathy. ${ }^{15,16}$ In various forms of MD, expression profiling of the muscle reveals several genes related to the increases in connective tissue, fibrosis, and collagen content that are TGF- $\beta$ dependent. ${ }^{17}$ The main source of collagen, and of the enzymes responsible for its post-translational modifications, is the myofibroblasts. ${ }^{15,18}$ During the fibroblast-tomyofibroblast trans-differentiation, regulated mainly by TGF- $\beta$, the fibroblasts undergo a phenotypic change to proliferative and contractile myofibroblasts, and acquire migratory capabilities. ${ }^{19}$ In DMD, fibroblasts have a profibrotic phenotype that is enhanced by TGF- $\beta$ treatment, and in culture they secrete higher levels of collagen than normal muscle fibroblasts. ${ }^{20}$ TGF- $\beta$ release from necrotic myofibers and infiltrating macrophages contributes to increased fibrosis and the progressive loss of muscle regeneration, ${ }^{21}$ whereas inhibition of TGF- $\beta / \mathrm{Smad} 3$ signaling ameliorates the pathological phenotype in dystrophic mice. ${ }^{15,16,22-24}$

One of the proteins involved in cell migration and fibrosis, which is under the control of TGF- $\beta$, is moesin. ${ }^{25-29}$ Moesin belongs to the ezrin-radixin-moesin (ERM) family of proteins that play structural and regulatory roles in the assembly and stabilization of plasma membrane interactions through their ability to interact with transmembrane proteins and the cytoskeleton. $^{30,31}$ ERM proteins act as cross-linkers between membranes and the cortical actin cytoskeleton. In doing so, they provide structural links to strengthen the cell cortex and facilitate several key cellular processes, including membrane dynamics, substrate adhesion, cell survival, determination of cell shape, polarity, formation of membrane protrusions, cell adhesion, and motility. ${ }^{32,33}$ The physiological function of ERM proteins is highly reliant on phosphorylation-dependent conformational changes, which modulate their membrane protein-actin cytoskeletal cross-linking capacity in response to growth factor, chemokine, and antigen stimulation. ${ }^{34}$

In this study, we assessed the expression of moesin in the most affected skeletal muscles in mouse models of various MDs and MD patients. We elucidated the cells responsible for its synthesis and correlated its presence with muscle fibrosis.

\section{Materials and Methods}

\section{Materials}

Halofuginone bromhydrate was obtained from Akashi Therapeutics Inc. (Cambridge, MA); polyclonal mousespecific collagen type I (1:50), monoclonal moesin, and anti-moesin (phospho T558) antibodies were from Abcam (Cambridge, UK); and prolyl 4 hydroxylase $\beta$ monoclonal antibodies (1:25), polyclonal anti-macrophage (1:250), and anti-ezrin (1:100) antibodies were from Acris (Hiddenhausen, Germany). Polyclonal moesin for double immunostaining (1:50), radixin (1:50), and monoclonal Pax7 (1:50) antibodies were from Proteintech (Rosemont, IL). Goat antimouse IgG antibodies with Alexa Fluor dye (Molecular Probes, Carlsbad, CA) and Cy3 anti-goat antibodies (Jackson ImmunoResearch Laboratories, Inc., West Grove, PA) were used as secondary antibodies.

\section{Total RNA Isolation and Real-Time PCR}

Total RNA was isolated using TriReagent (Molecular Research Center, Cincinnati, OH), according to the manufacturer's instructions. Diaphragm RNA $(0.5 \mu \mathrm{g})$ was reverse transcribed to single-stranded cDNA by SuperScript II Reverse Transcriptase and oligo(dT) plus random primers (Invitrogen, Waltham, MA). Real-time PCR was performed with 10-ng cDNA on a model 7000 sequence analysis system (Applied Biosystems, Foster City, CA) with the Absolute Blue SYBR Green ROX Mix (ABgene, Epsom, UK). Dissociation curves were analyzed after each real-time PCR to confirm the presence of only one product and the absence of primer dimer formation. The primer sequences used for RTPCR of the moesin gene (Msn) were as follows: $5^{\prime}$-GCCCCGGACTTTGTGTTCTA-3' (forward) and 5'-CGACGCATGTACAGCTCATGA-3' (reverse). The product size was 92 bp. The Ying Yang 1 (YYI) gene [5'-GGCAAAGCGTTCGTTGAGA-3' (forward) and 5'-GCCTTCGAATGTGCACTGAAA- $3^{\prime}$ (reverse)] was used to normalize the results.

\section{Patients}

Cryosections of the quadriceps femoris (QF) of DMD patients aged $3,4,5,8,9$, and 9 years with creatine kinase levels of 4156, 14,000, 23,000, 14,000, 5500, and 9000 $\mathrm{U} / \mathrm{L}$, respectively, who exhibited lack of dystrophin, were from the muscle biopsy bank at the Neuromuscular Centre, University of Padova (Padova, Italy). The cryosections of Ullrich CMD (UCMD) and merosin-deficient CMD biopsy specimens were from the histopathology laboratory from the Institute de Myologie, Groupe Hospitalier Pitié-Salpêtrière (Paris, France) (Table 1).

\section{Animals}

All animal experiments were performed in accordance with the guidelines of the Volcani Center Institutional Committee for Care and Use of Laboratory Animals (IL-433/13). C57BL/10ScSn-Dmd $d^{m d x} / \mathrm{J}(m d x)$ mice, which do not express dystrophin, were used as a model for DMD; B6.129$d y s f^{\mathrm{tm} 1 \mathrm{Kcam}} / \mathrm{Mmmh}\left(d y s f^{-1-}\right)$ mice, in which a 12-kb region of the $d y s f$ gene containing the last three exons (exons 53 to 55, amino acids 1983 to 2080) is deleted, thereby removing the transmembrane domain, were used as a model for dysferlinopathy; C57BL/6J Lama2 ${ }^{\text {dy2J }}\left(d y^{2 J} / d y^{2 J}\right)$ homozygous 
Table 1 MD Patients

\begin{tabular}{llll}
\hline Disease & Mutated gene & Age of biopsy & Muscle \\
\hline DMD & Dystrophin & 3 years & Quadriceps femoris \\
DMD & Dystrophin & 4 years & Quadriceps femoris \\
DMD & Dystrophin & 5 years & Quadriceps femoris \\
DMD & Dystrophin & 8 years & Quadriceps femoris \\
DMD & Dystrophin & 9 years & Quadriceps femoris \\
DMD & Dystrophin & 9 years & Quadriceps femoris \\
UCMD & COL6A1 & 4.5 years & Deltoid \\
UCMD & COL6A1 & 10 months & Paraverterbral \\
UCMD & COL6A1 & 33 years & Deltoid \\
UCMD & COL6A3 & Adult* & Deltoid \\
MDC1A & LAMA2 & 10 years & Deltoid \\
MDC1A & LAMA2 & 4 years & Quadriceps \\
\hline
\end{tabular}

DMD, Duchenne muscular dystrophy; MD, muscular dystrophy; MDC1A, merosin-deficient congenital muscular dystrophy; UCMD, Ullrich congenital muscular dystrophy.

*>20 years of age.

mice were used as a model for laminin- $\alpha 2$ deficiency (CMD); and C57/BL/6J mice were used as the wild type (Jackson Laboratory, Bar Harbor, ME). Mice were housed in cages under a constant photoperiod (12/12 hours light/ dark) with free access to food and water.

\section{Preparation of Sections and Immunohistochemistry}

The mice were injected i.p. with halofuginone-an inhibitor of Smad3 phosphorylation downstream of the TGF- $\beta$ pathway. ${ }^{35-37}$ The $m d x(n=10)$ and $d y s f^{-1-}(n=8)$ mice were injected with halofuginone at $7.5 \mu \mathrm{g}$ per mouse, three times a week for 10 weeks, starting from the ages of 4 weeks and 5 months, respectively. ${ }^{15,38}$ The $d y^{2 J} / d y^{2 J}$ mice $(n=8)$ were treated with $5 \mu \mathrm{g}$ halofuginone three times a week for 5 weeks, starting at the age of 3 weeks, ${ }^{18}$ and the control mice were injected with saline. At the end of the experiments, diaphragms $(m d x)$, quadriceps $\left(d y s f^{-1-}\right)$, and gastrocnemius $\left(d y^{2 J} / d y^{2 J}\right)$, which are the most affected muscles in these mice, were taken for histopathology. Biopsy specimens were collected and fixed, and sections were prepared as previously described. $^{38}$ Muscles were immunostained with single or double antibodies, as specified, and nuclei were detected with DAPI. At least 20 images of five tissue sections from four different mice per group were obtained for each analysis.

\section{Confocal Microscopy}

Microscopic observation and image acquisition were performed with an Olympus IX 81 inverted confocal laserscanning microscope (Fluoview 500; Olympus, Tokyo, Japan) equipped with a 405-nm diode laser, a 488-nm argon-ion laser, a 543-nm helium-neon laser, and a $60 \times 1.0$ numerical aperture PlanApo water-immersion objective. DAPI was excited at $405 \mathrm{~nm}$, and the emission was collected through a BA 430-460 filter; GREEN was excited at $488 \mathrm{~nm}$, and the emission was collected through a BA 505-525 filter; RED was excited at $543 \mathrm{~nm}$, and the emission was collected through a BA 560 interference filter. The transmitted-light images were obtained by Nomarski differential interference contrast microscopy. Cell nuclei were stained with DAPI (1:1000) for 2 minutes and washed with
A

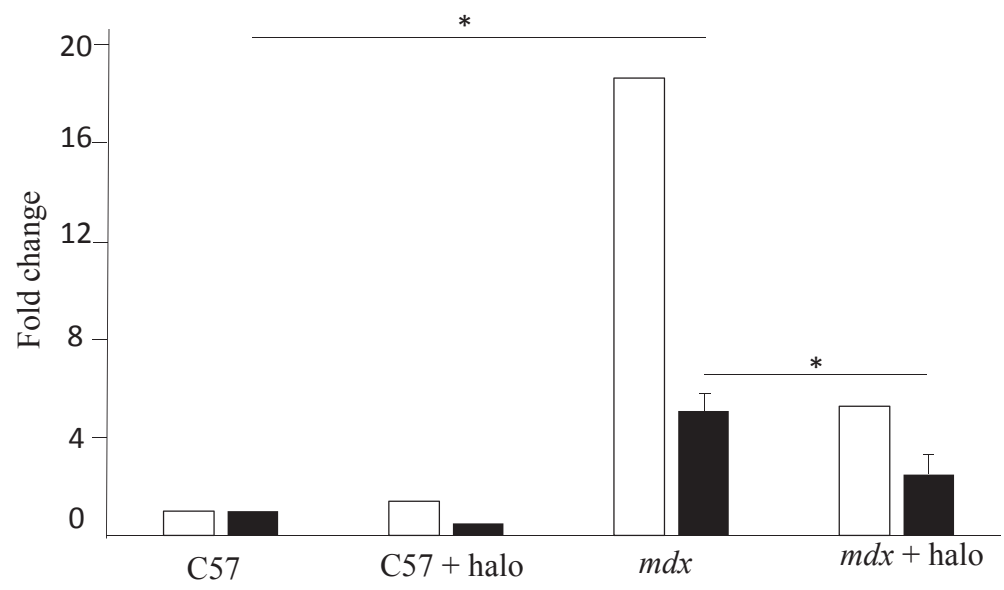

B

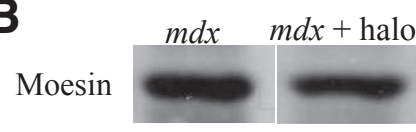

GAPDH
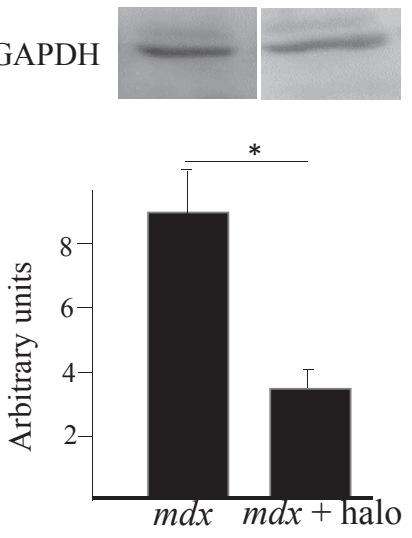

Figure 1 A: $C 57 / B L$ and $m d x$ mice were injected i.p. with halofuginone (halo) at $7.5 \mu \mathrm{g}$ per mouse, three times a week for 10 weeks starting from the age of 4 weeks. Impact of halofuginone treatment on the transcriptome of the diaphragm of $m d x$ mice was determined in two separate experiments using Affymetrix GeneChip oligonucleotide MG430A and MG430B microarray-based transcriptional profiling (white bars). The microarray results were confirmed by RT-PCR analysis (black bars). The results are from two separate experiments. B: Western blots of $m d x$ diaphragms (pool of three) with and without halofuginone treatment. Glyceraldehyde-3-phosphate dehydrogenase (GAPDH) was used as the loading control. Data are expressed as means \pm SEM. $n=3$ mice in each group (A). ${ }^{*} P<0.05$. 

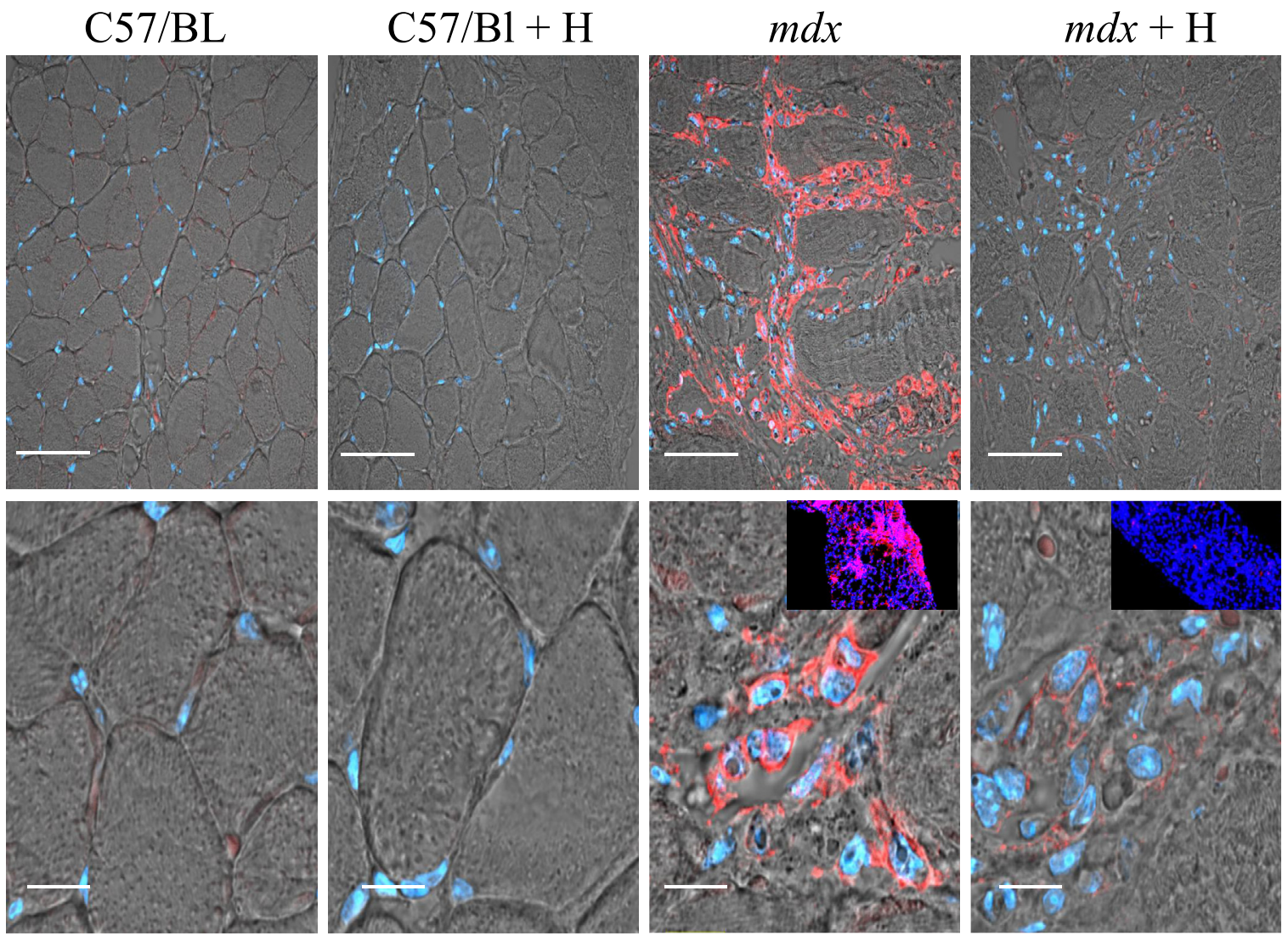

Figure 2 Effect of halofuginone on moesin in the diaphragm of $m d x$ mice. Mice (C57/BL) or $m d x$ were administered with halofuginone (H) i.p. at $7.5 \mu \mathrm{g}$ per mouse, three times a week for 10 weeks starting from the age of 4 weeks. Diaphragms - the most affected muscle in these mice-were taken for moesin immunostaining (red). Insets: A large area of the muscle. Note the major increase in moesin content in the $m d x$ mice compared to controls and the decrease in moesin level after halofuginone treatment. Scale bars: $50 \mu \mathrm{m}$ (top row); $10 \mu \mathrm{m}$ (bottom row). Original magnification, $\times 40$ (insets).

phosphate-buffered saline for 5 minutes. Goat anti-mouse IgG antibodies with Alexa Fluor dye were used.

\section{Microarray Analysis}

C57/BL/6J (wild type) and $m d x$ mice ( $n=4$ per group) were injected with either saline or halofuginone $(7.5 \mu \mathrm{g}$ per mouse) three times a week starting at 3 weeks of age. At 5 weeks of age, diaphragms were collected and pooled, and the impact of halofuginone treatment on the transcriptome of the diaphragm of $m d x$ mice was determined in two separate experiments using Affymetrix GeneChip oligonucleotide MG430A and MG430B microarray-based transcriptional profiling (Affymetrix, Santa Clara, CA), as previously described. ${ }^{39}$ The microarray data were pooled and analyzed using GeneSpring Gx11 Expression software version 11.0 (Agilent Technologies, Santa Clara, CA) and normalized using Robust Multichip Average. ${ }^{40}$

\section{Western Blot Analysis}

Western blot analysis was performed as previously described. ${ }^{41}$ Briefly, equal amounts of protein (diaphragm) were resolved by $10 \%$ SDS-PAGE and then transferred to nitrocellulose membranes (Bio-Rad Laboratories, Hercules, CA). After blocking, the membranes were incubated with mouse polyclonal moesin (1:4000) and rabbit polyclonal glyceraldehyde-3-phosphate dehydrogenase (1:500) antibodies.

\section{Results}

In our ongoing effort to identify fibrosis-related biomarkers associated with $\mathrm{MD}$, we previously performed a microarray analysis of $m d x$ and C57/BL wild-type diaphragms. ${ }^{23}$ Mice at 3 weeks of age were treated, or not, with the antifibrotic agent halofuginone ${ }^{23,38}$ for 2 weeks $(7.5 \mu \mathrm{g}$, three times a week). At the end of the experiments, the diaphragms (pools of three) were subjected to microarray analysis. The results (as fold increase compared to the wild type) revealed low levels of the Msn (moesin) gene in the diaphragms of the wild-type mice, which were not affected by halofuginone treatment, and up-regulation of Msn expression in the $m d x$ mice, which returned to close to control levels after halofuginone treatment. These results were validated by RT-PCR (Figure 1A). Halofuginone-dependent reduction in moesin level in the $m d x$ diaphragm was also demonstrated 

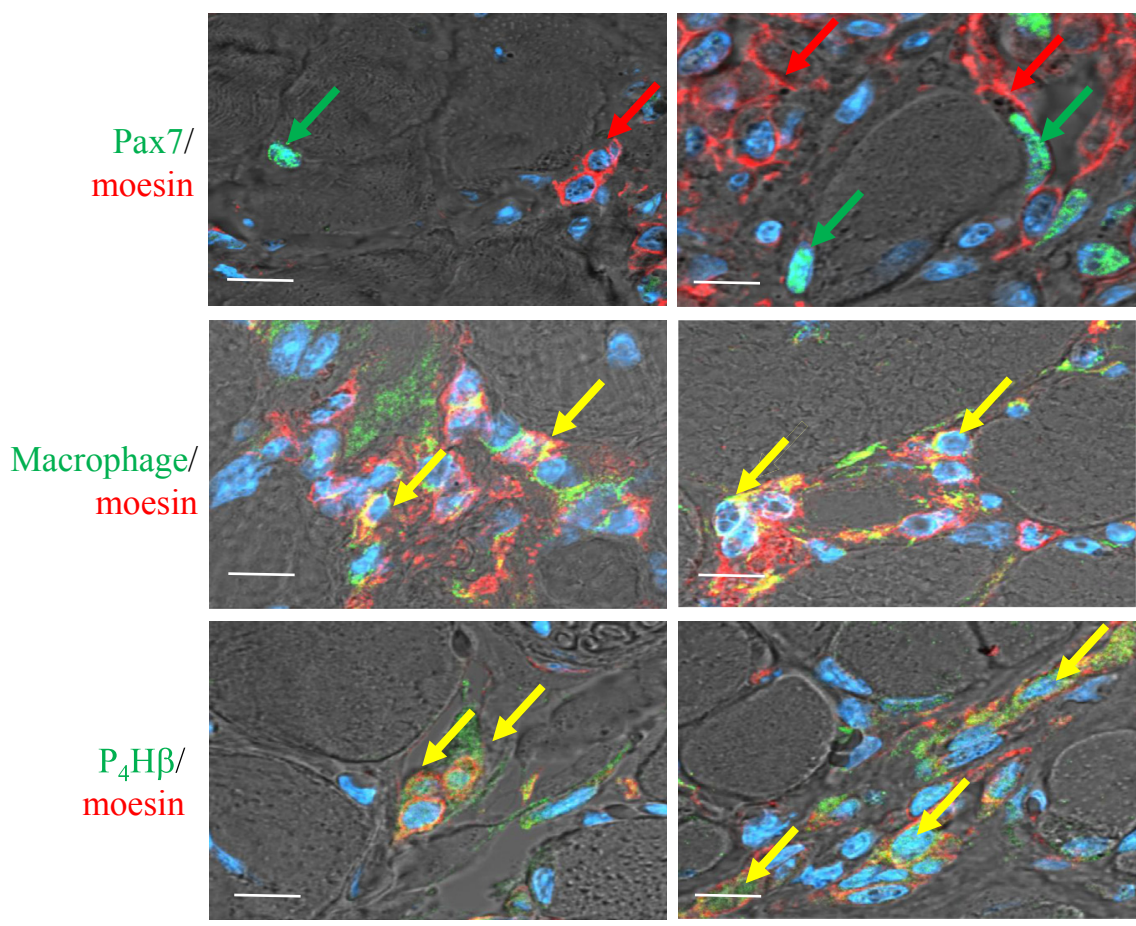

Figure 3 Cellular source of moesin. The diaphragms of $m d x$ mice were double immunostained for moesin (red) and Pax-7 (green; top row) with macrophage antibodies (green; middle row) or prolyl 4 hydroxylase $\beta\left(\mathrm{P}_{4} \mathrm{H} \beta\right.$; green; bottom row). Note that moesin does not colocalize with the Pax-7 that stained the satellite cells, whereas it does colocalize with the macrophages and myofibroblasts. Green arrows indicate Pax-7; red arrows, moesin; yellow arrows, colocalization of moesin with macrophages or myofibroblasts. Scale bar $=10 \mu \mathrm{m}$. by Western blot analysis (Figure 1B). To further elucidate the association between moesin and muscle fibrosis, $m d x$ and $\mathrm{C} 57 / \mathrm{BL}$ mice were treated, or not, with halofuginone i.p. $(7.5 \mu \mathrm{g}$ per mouse, three times a week starting from the age of 4 weeks) for 10 weeks, and the diaphragm was evaluated for the presence of moesin-positive cells by immunostaining. The diaphragm of wild-type mice (C57/BL) exhibited no moesin expression, regardless of halofuginone treatment, whereas high levels of moesin were observed in the diaphragms of the $m d x$ mice, which were almost completely abolished by the halofuginone treatment (Figure 2). At a higher magnification, the moesin-positive cells seemed to be imbedded in the fibrotic tissue between the myofibers (Figure 2). In the dystrophic muscles, this interstitial space is usually occupied by myofibroblasts and inflammatory cells that infiltrate the muscle at sites adjacent to centrally nucleated myofibers. ${ }^{18,42,43}$ To identify the moesin-expressing cells, we double immunostained the $m d x$ diaphragm with moesin antibodies together with antibodies against either Pax7, a marker for satellite cells, ${ }^{44}$ or prolyl 4 hydroxylase $\beta$, a major collagen cross-linking enzyme that is used as a marker for activated fibroblasts ${ }^{39,45}$ and macrophages. ${ }^{15,46}$ The moesin-positive cells (Figure 3) residing between the myofibers were distinct from the Pax7-positive ones (Figure 3), the latter located under the basal lamina of the myofibers and corresponding to the satellite cell position (Figure 3). Many of the macrophages (Figure 3) and almost all of the myofibroblasts (Figure 3) were positive for moesin (Figure 3). Radixin, another member of the ERM family, was also expressed by the prolyl 4 hydroxylase $\beta$-positive myofibroblasts infiltrating the dystrophic diaphragm of the $m d x$ mice (Figure 4A). On the other hand, ezrin, the third protein member of the ERM family, was found in the myofiber membranes with sarcoplasmic staining in both the diaphragm of the $m d x$ mice (Figure $4 \mathrm{~B}$ ) and the QF muscle of a 4-year-old DMD patient (Figure 4B), and was probably synthesized by the myofibers themselves.

The gastrocnemius of the $d y^{2 J} / d y^{2 J}$ homozygous mice that were used as a model for CMD also exhibited a high number of cells expressing moesin (Figure 5A) and myofibers with central nuclei resulting from previous muscle damage and subsequent regeneration (Figure 5A). Halofuginone treatment, which inhibited fibrosis in these mice by reducing Smad3 phosphorylation, resulted in a favorable histopathology, including reduction in the number of myofibers with central nuclei, reduction in the variability in muscle fiber size, ${ }^{18}$ and a major reduction in the number of moesin-positive cells. In the $d y s f^{-1-}$ mice, representing dysferlinopathy with a late onset of the disease, ${ }^{47}$ moesin appeared in cells residing between the myofibers and in the dystrophic myofibers, whereas no moesin was observed in the wild-type mice (Figure 5B).

The levels of moesin were evaluated by immunohistochemistry in skeletal muscle biopsy specimens from healthy and DMD patients. Low levels of moesin were detected in healthy QF muscle (Figure 6A), whereas a major increase in moesin level was observed in the QF muscle of patients aged 4, 5, and 8 years (Figure 6, B-D, respectively). The moesin was visualized surrounding the cell nuclei that were infiltrating the muscle between the myofibers. Double immunostaining with moesin (red) and collagen type I (green) antibodies revealed that, although the healthy muscle exhibits low levels of these proteins (Figure 7A), all of the patients display the moesin-positive cells embedded 
A

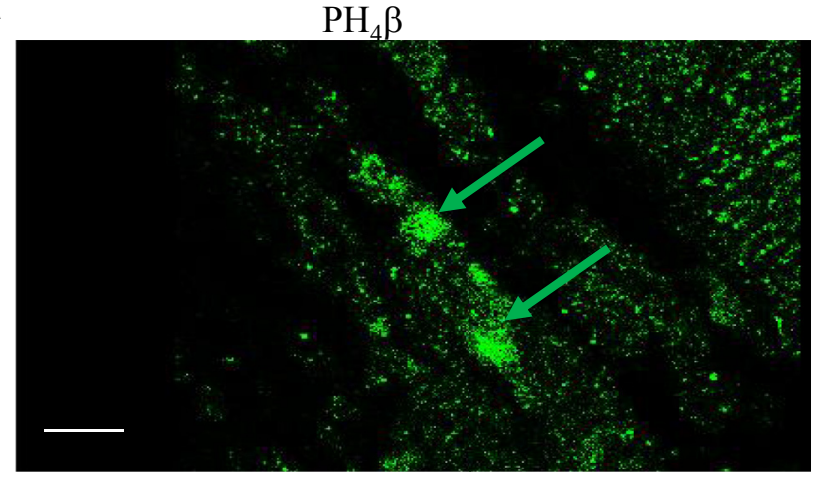

B

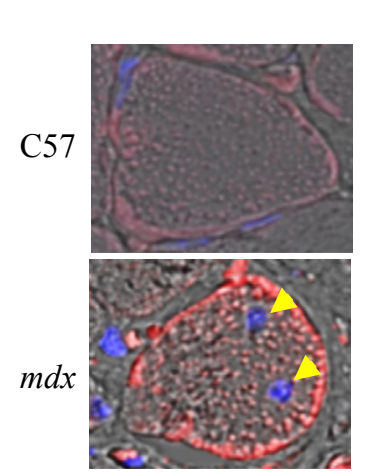

Mouse

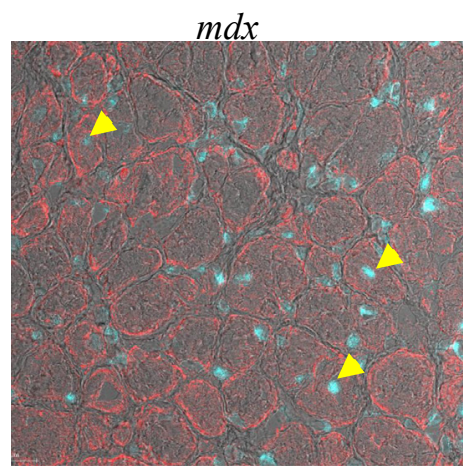

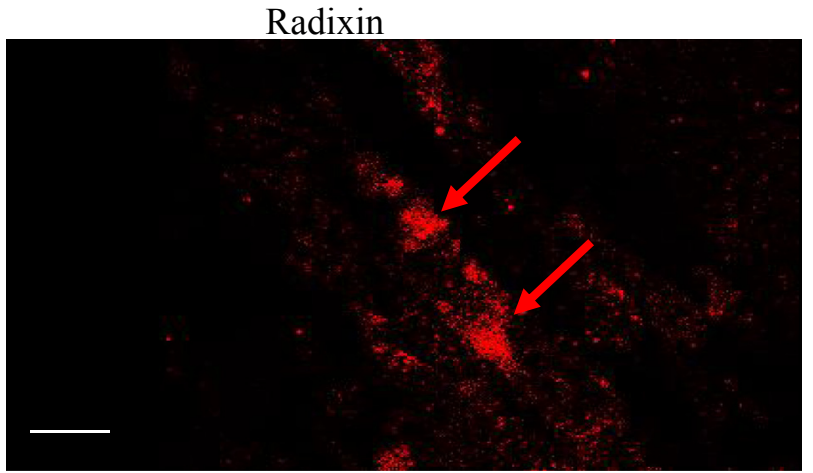

Human

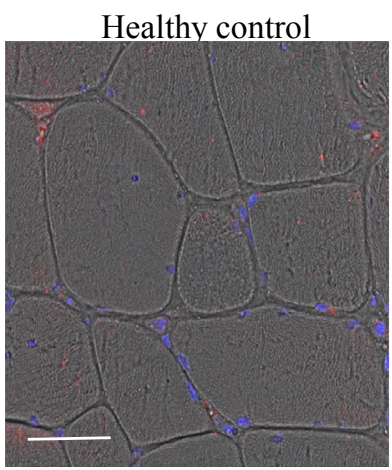

Figure 4 A: Radixin is synthesized by myofibroblasts. Diaphragms of $m d x$ mice were double immunostained with radixin (red) and prolyl 4 hydroxylase $\beta$ $\left(\mathrm{P}_{4} \mathrm{H} \beta\right.$; green) antibodies. Note the colocalization of both proteins $\left(\mathrm{P}_{4} \mathrm{H} \beta\right.$, green arrows; radixin, red arrows). B: Ezrin in mouse and human muscle biopsy specimens. Left panels: High resolution of myofibers from diaphragms of C57 (control) and $m d x$ mouse and a low-resolution image showing a large area of $m d x$ diaphragm. Right panels: Quadriceps femoris muscle of a healthy control and a 4-year-old DMD patient. Immunostained with ezrin antibodies (red), and nuclei were stained with DAPI (blue). Arrowheads point to myofibers' central nuclei. Note that in the $m d x$ mouse and in the DMD patient, ezrin colocalized with the myofiber membrane. Scale bars: $5 \mu \mathrm{m}$ (A); $50 \mu \mathrm{m}$ (B).

within the fibrotic area associated with high levels of collagen type I, independent of patient age (Figure 7, B-F). In the 9-year-old DMD patient, some myofibers expressed moesin that colocalized with the myofiber membrane (Figure 7F). Moesin colocalization with the myofiber membrane was observed also in the diaphragm of aging $(9$ months) $m d x$ mice. Double immunostaining revealed that the membrane-associated moesin was unphosphorylated (data not shown).

In other MDs, such as UCMD1 with mutations in COL6A1 (Figure 8, A-C) or COL6A3 (Figure 8D), and merosin-deficient CMD patients with LAMA2 mutations (Figure 8, E and F), moesin was expressed by cells embedded within the fibrotic areas, as observed in the DMD patients (Figure 8). Moreover, older patients, such as the 33 -year-old UCMD patient with a mutation in COL6Al (Figure $8 \mathrm{C}$ ), the adult ( $>20$ years of age) UCMD patient with a mutation in COL6A3 (Figure 8D), and the 10-yearold merosin-deficient CMD patient with the LAMA2 mutation (Figure 8E), also demonstrated moesin colocalization with the myofiber perimeter (Figure 8).

Activation of moesin requires its phosphorylation, ${ }^{48,49}$ which occurs on threonine residues. ${ }^{33,50}$ Double immunostaining of the QF muscle of the 4-year-old DMD patient (Figure 9A), the gastrocnemius muscle of the $d y^{2 J} / d y^{2 J}$ mice (Figure 9B) with moesin (green) and phospho-moesin (red) antibodies, and Western blot of $m d x$ diaphragms (Figure 9C) revealed that in all cases part of the moesin is phosphorylated.

\section{Discussion}

Fibrosis at various levels is a common feature of the dystrophic muscle histopathology of various MDs. ${ }^{23,51,52}$ In this study, we demonstrate that moesin is part of the fibrotic reaction, on the basis of the following findings: i) moesin was expressed by the myofibroblasts infiltrating the dystrophic muscles that are the main source of the extracellular matrix proteins of the fibrotic tissue (Figure 3); ii) moesin was also expressed by macrophages that are the source of TGF- $\beta$, the main regulator of the synthesis of extracellular matrix proteins; iii) all of the moesin-positive cells, in both the animal models (Figures 2 and 5) and patients with various MDs (Figures 6-8), were embedded within the fibrotic area of the muscles near collagen type I, which is the main 
A
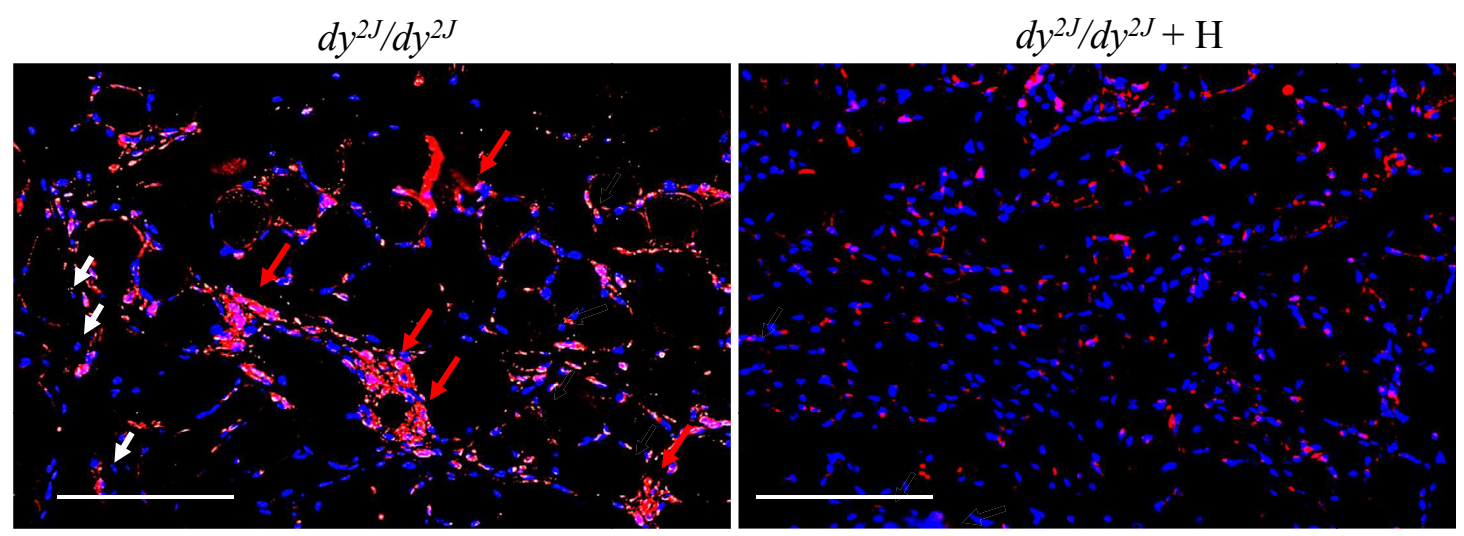

B
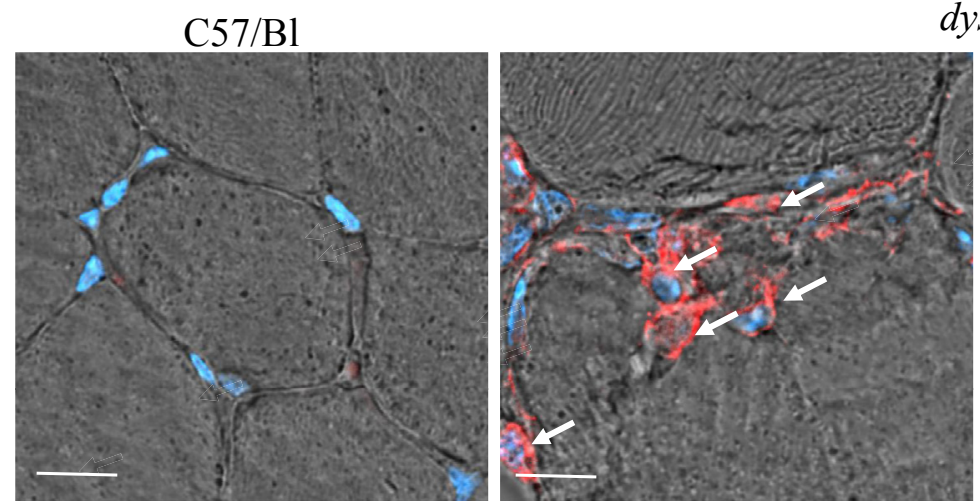

dysf-/-

Figure 5 A: Moesin in $d y^{2 J} / d y^{2 J}$ homozygous mice. The gastrocnemius $d y^{2 J} / d y^{2 J}$ mice with and without halofuginone (H) treatment were immunostained with moesin antibodies. In the $d y^{2 J} / d y^{2 J}$ mice, the cells expressing moesin (red arrows) reside between the myofibers, some of which are with central nuclei (white arrows). Halofuginone treatment resulted in a reduced number of myofibers with central nuclei, reduced variability in muscle fiber size, and a major reduction in the number of moesin-positive cells. B: Moesin in $d y s f^{-1-}$ mice. Quadriceps of a 6-month-old dysf $f^{--}$mouse was stained with moesin antibodies. Moesin (white arrows) is expressed by both cells residing between the dystrophic muscle myofibers (middle panel) and the dystrophic myofibers themselves (right panel), whereas no moesin was observed in the wild-type mouse. Scale bars: $100 \mu \mathrm{m}$ (A); $10 \mu \mathrm{m}$ (B).

protein in fibrosis; iv) inhibition of fibrosis and reduction of the levels of collagen type I by halofuginone in the $m d x$ and $d y^{2 J} / d y^{2 J}$ mice ${ }^{18,38}$ resulted in a reduction in moesin expression (Figures 1, 2, and 5); and v) moesin is involved in fibrosis of other tissues as well, such as renal fibrosis and the cornea, ${ }^{28,29}$ and a decrease in liver fibrosis is observed in moesin-deficient mice. ${ }^{25}$ Moesin colocalizes with fibroblasts and inflammatory cells in other systems as well, ${ }^{53}$ and overexpression of moesin is related to motility and invasiveness. ${ }^{54}$
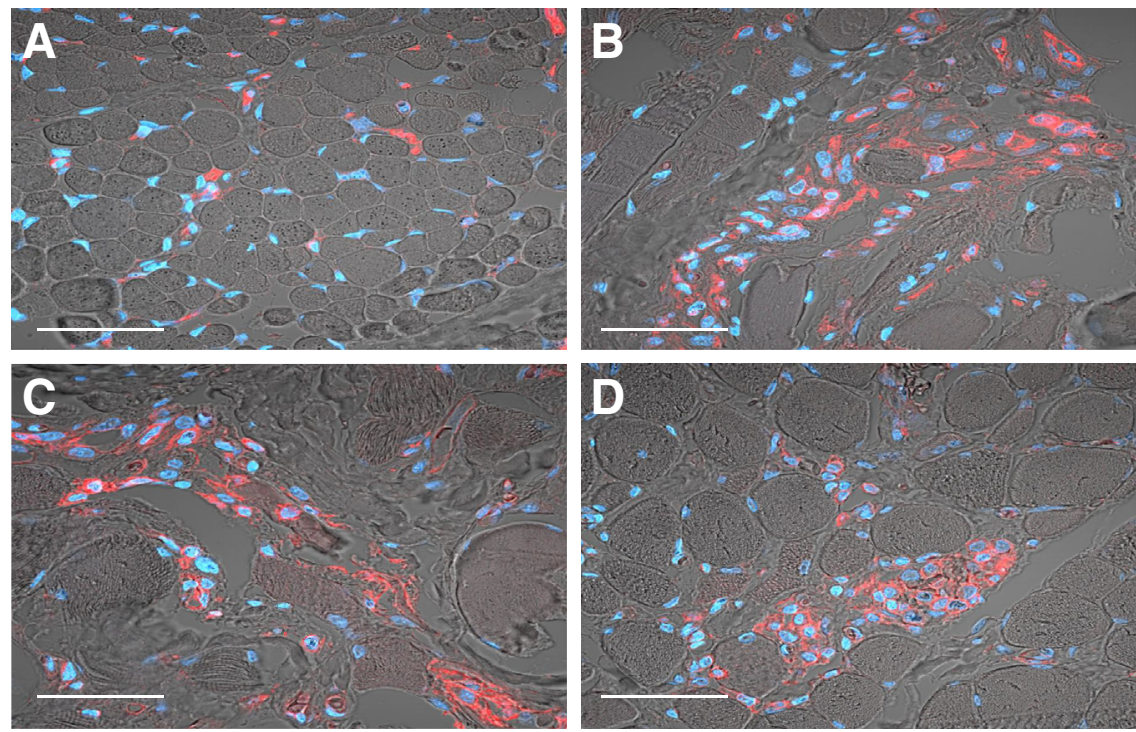

Figure 6 Moesin immunohistochemistry in quadriceps femoris muscles of DMD patients. Healthy control (A) and 4-year-old (B), 5-year-old (C), and 8-year-old (D) DMD patients. Note the major increase in moesin in the dystrophic muscle independent of age (red staining) compared to the healthy one. Scale bars $=50 \mu \mathrm{m}$. 

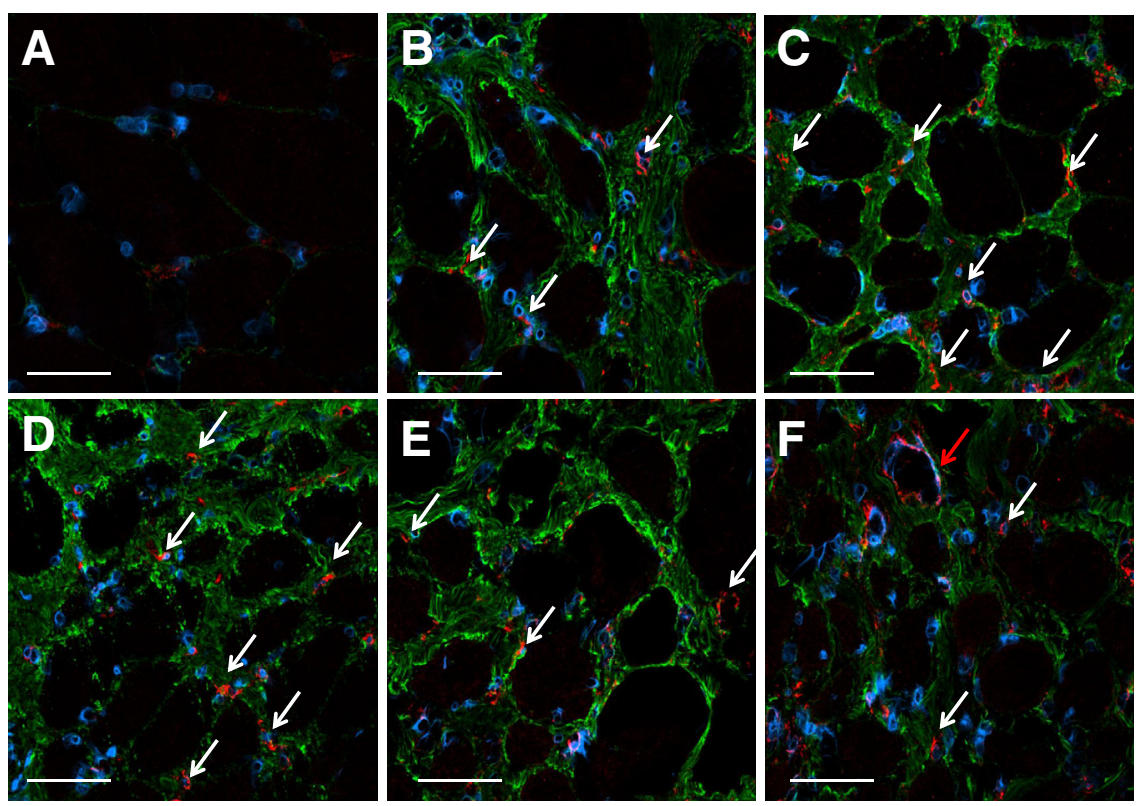

Figure 7 Double immunostaining of quadriceps femoris from DMD patients with moesin and collagen type I. Healthy control (A) and 3-year-old (B), 4-year-old (C), 5-year-old (D), 8-year-old (E), and 9-year-old (F) DMD patients. White arrows indicate moesin-producing cells (red). Collagen type I stained green. Note the almost complete absence of both moesin and collagen type I in the healthy muscle compared to the dystrophic muscles. The moesin-positive cells were embedded within the fibrotic area associated with high levels of collagen type I independent of patient age (white arrows). Note that in the 9-year-old patient, some myofibers expressed moesin that colocalized with the myofiber membrane (red arrow). Scale bars $=50 \mu \mathrm{m}$.
Moesin was up-regulated in the muscles of all animal models and patients of different MDs, independent of the mutations and of patients' age. These results are further supported by the gene expression data mining that revealed an increase in moesin levels in the gastrocnemius and diaphragm muscles of $m d x$ mice ${ }^{55,56}$ and in quadriceps biopsy specimens taken from DMD patients. 57,58

In dysferlinopathy, moesin was found to have a physical interaction with dysferlin. ${ }^{59}$ In the $d y s f^{-1-}$ mice, in addition to the infiltrating cells surrounding the myofibers that are involved in the fibrotic reaction, moesin was also detected within the myofibers (Figure 5). This is in agreement with the suggestion that in dysferlinopathy, moesin is involved in muscle-membrane resealing as well. ${ }^{59}$ Moreover, on careful examination of the localization of moesin expression in patients' biopsy specimens, we observed that in addition to the macrophages and myofibroblasts, there was agerelated expression of moesin by the myofibers themselves
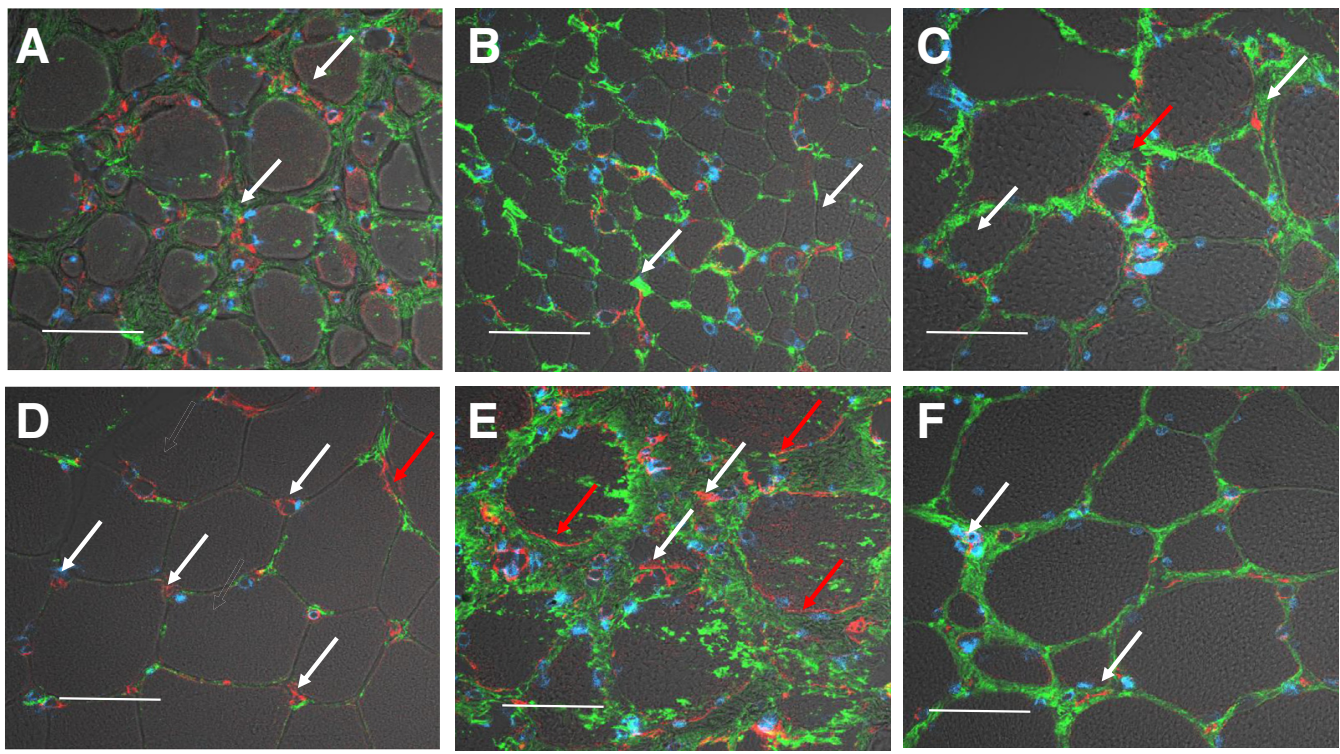

Figure 8 Double immunostaining of muscles from MD patients with moesin and collagen type I. A: Deltoid muscle of 4.5-year-old Ullrich CMD (UCMD) patient with mutation in Col6A1. B: Paravertebral muscle of 10-month-old UCMD patient with mutation in Col6A1. C: Deltoid muscle of 33-year-old UCMD patient with mutation in Col6A1. D: Deltoid muscle of an adult ( $>20$ years of age) UCMD patient with mutation in Col6A3. E: Deltoid of 10-year-old merosindeficient CMD (MDC1A) patient with LAMA2 mutation. F: Deltoid of 4-year-old MDC1A patient with LAMA2 mutation. Red arrows indicate moesin colocalization with the myofiber perimeter in older patients, whereas white arrows indicate moesin-producing cells embedded in the collagen matrix (green) in young patients. Scale bars $=50 \mu \mathrm{m}$. 

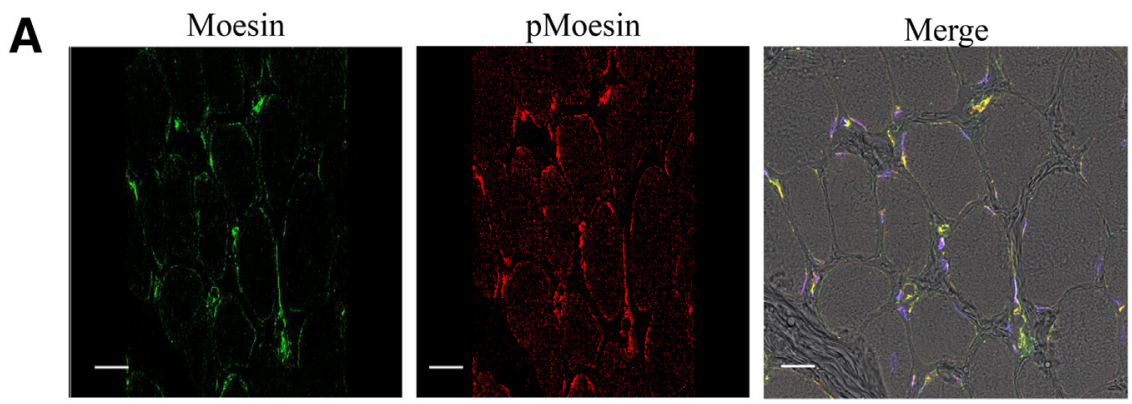

B
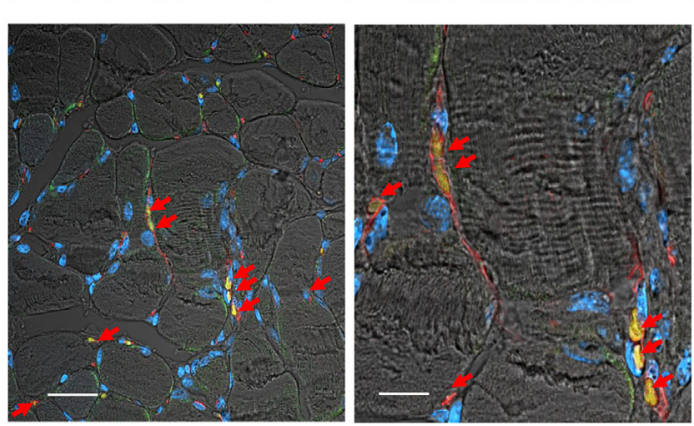

Figure 9 Phosphorylation of moesin. A: Double immunostaining of quadriceps femoris muscle of 4-year-old DMD patient with moesin (green) and phospho-moesin (pMoesin; red) antibodies. Note that moesin is colocalized with phospho-moesin on merging. B: Gastrocnemius of 8-week-old $d y^{2 J} / d y^{2 J}$ mouse was double immunostained with moesin (green) and phospho-moesin (red) antibodies. The figure depicts the merged staining at two different magnifications. Most of the moesin in the gastrocnemius dystrophic muscle of the $d y^{2 J} / d y^{2 J}$ mice was phosphorylated (arrows). C: Western blot of the diaphragms of three different $m d x$ mice staining with moesin and pMoesin antibodies. The $\alpha$-tubulin served as a loading control. Scale bars: $50 \mu \mathrm{m}$ (B, left panel); $20 \mu \mathrm{m}$ (A and B, right panel).
(Figures 7 and 8). Moesin was only observed around the myofibers and colocalized with the myofiber membrane in older patients of DMD, UCMD, and merosin-deficient CMD and aged $m d x$ mice. This observation has to be validated with a larger number of patients and colocalization with sarcolemmal proteins.

Radixin, another member of the ERM family, was also synthesized by the myofibroblasts, whereas ezrin was localized to the myofiber membrane (Figure 4), suggesting that differential expression and distribution of ERM proteins are involved in the cross talk between the damaged muscle fibers and the infiltrating myofibroblasts and inflammatory cells involved in fibrosis. This cross talk might explain our previous observation that the macrophages and myofibroblasts infiltrate the dystrophic muscle at the same location, in areas adjacent to centrally nucleated myofibers, and from there spread to the entire muscle. ${ }^{15}$ Cell-matrix adhesion proteins play a key role in the acquisition of structurally and functionally distinct domains of the plasma membrane and cytoplasm; together with transmembrane receptors, this triggers the assembly of the actin cytoskeleton and regulatory proteins, forming a large multiprotein complex. ${ }^{60}$ The ERM proteins participate in the regulation of these networks through their versatile interaction with membrane proteins, the actin cytoskeleton, and signaling molecules. ${ }^{61}$ The ERM protein family is mainly regulated through conformational changes induced by phospholipids and kinase-mediated phosphorylation that result in activation of the proteins. ${ }^{50,61,62}$ Part of the moesin in the muscle of the DMD patients and in $m d x$ and CMD animal models was found in its phosphorylated form (Figure 9). The active phosphorylated moesin is involved in cell migration, ${ }^{49}$ which further supports its involvement in myofibroblast and macrophage invasion of the dystrophic muscle. The importance of moesin phosphorylation for migration and invasion ${ }^{63,64}$ and the observation that dephosphorylation of moesin results in cell apoptosis ${ }^{65}$ suggest that moesin phosphorylation may become a novel target for inhibition of fibrosis in MDs.

Disease-specific and surrogate biomarkers play a central diagnostic and therapeutic role in muscle pathology. Validated biomarkers in MDs provide a deeper insight into disease pathogenesis, suggest new therapeutic approaches, serve as acute readouts of drug effects, define and interpret proof of concept, and can be useful as surrogate outcome measures to predict later clinical benefits. ${ }^{66,67}$ In this study, we demonstrated that moesin is a novel and highly needed fibrosisrelated and disease-associated biomarker for MDs. Together with other fibrosis-related and disease severity biomarkers, such as collagen triple helix repeat containing 1 and periostin, ${ }^{39,68}$ moesin can be used in both preclinical research and clinical trials to assess the efficacy of antifibrotic treatments. The quest today is for urine and blood biomarkers. Elevated levels of moesin were demonstrated in urine of rats with unilateral ureteral obstruction, ${ }^{69}$ and anti-moesin antibodies were observed in patient's plasma of various diseases. ${ }^{70,71}$ It is still to be determined whether this is the case in MDs.

In summary, the results of this study may pave the way, on the one hand, for exploiting moesin as a target for intervention in MDs, and on the other, for its use as part of a battery of biomarkers to evaluate treatment success in clinical trials.

\section{Acknowledgments}

We thank Edouard Belauso for help with the confocal microscopy. 


\section{References}

1. Dalkilic I, Kunkel LM: Muscular dystrophies: genes to pathogenesis. Curr Opin Genet Dev 2003, 13:231-238

2. Davies KE, Nowak KJ: Molecular mechanisms of muscular dystrophies: old and new players. Nat Rev Mol Cell Biol 2006, 7:762-773

3. Desguerre I, Mayer M, Leturcq F, Barbet JP, Gherardi RK, Christov C: Endomysial fibrosis in Duchenne muscular dystrophy: a marker of poor outcome associated with macrophage alternative activation. J Neuropathol Exp Neurol 2009, 68:762-773

4. Emery AE: The muscular dystrophies. Lancet 2002, 359:687-695

5. Finsterer J, Stollberger C: The heart in human dystrophinopathies. Cardiology 2003, 99:1-19

6. Bostick B, Yue Y, Long C, Marschalk N, Fine DM, Chen J, Duan D: Cardiac expression of a mini-dystrophin that normalizes skeletal muscle force only partially restores heart function in aged $\mathrm{mdx}$ mice. Mol Ther 2009, 17:253-261

7. Passerini L, Bernasconi P, Baggi F, Confalonieri P, Cozzi F, Cornelio F, Mantegazza R: Fibrogenic cytokines and extent of fibrosis in muscle of dogs with X-linked golden retriever muscular dystrophy. Neuromuscul Disord 2002, 12:828-835

8. Quinlan JG, Hahn HS, Wong BL, Lorenz JN, Wenisch AS, Levin LS: Evolution of the mdx mouse cardiomyopathy: physiological and morphological findings. Neuromuscul Disord 2004, 14:491-496

9. Bernasconi P, Di Blasi C, Mora M, Morandi L, Galbiati S, Confalonieri P, Cornelio F, Mantegazza R: Transforming growth factor-beta1 and fibrosis in congenital muscular dystrophies. Neuromuscul Disord 1999, 9:28-33

10. Bernasconi P, Torchiana E, Confalonieri P, Brugnoni R, Barresi R, Mora M, Cornelio F, Morandi L, Mantegazza R: Expression of transforming growth factor-beta 1 in dystrophic patient muscles correlates with fibrosis: pathogenetic role of a fibrogenic cytokine. J Clin Invest 1995, 96:1137-1144

11. Murakami N, McLennan IS, Nonaka I, Koishi K, Baker C, Hammond-Tooke G: Transforming growth factor-beta2 is elevated in skeletal muscle disorders. Muscle Nerve 1999, 22:889-898

12. Ishitobi $\mathrm{M}$, Haginoya $\mathrm{K}$, Zhao $\mathrm{Y}$, Ohnuma A, Minato J, Yanagisawa T, Tanabu M, Kikuchi M, Iinuma K: Elevated plasma levels of transforming growth factor betal in patients with muscular dystrophy. Neuroreport 2000, 11:4033-4035

13. Zhao Y, Haginoya K, Sun G, Dai H, Onuma A, Iinuma K: Plateletderived growth factor and its receptors are related to the progression of human muscular dystrophy: an immunohistochemical study. J Pathol 2003, 201:149-159

14. Talim B, Kale G, Topaloglu H, Akçören Z, Caglar M, Gögüş S, Elkay M: Clinical and histopathological study of merosin-deficient and merosin-positive congenital muscular dystrophy. Pediatr Dev Pathol 2000, 3:168-176

15. Halevy O, Genin O, Barzilai-Tutsch H, Pima Y, Levi O, Moshe I, Pines M: Inhibition of muscle fibrosis and improvement of muscle histopathology in dysferlin knock-out mice treated with halofuginone. Histol Histopathol 2013, 28:211-226

16. Demonbreun AR, Allen MV, Warner JL, Barefield DY, Krishnan S, Swanson KE, Earley JU, McNally EM: Enhanced muscular dystrophy from loss of dysferlin is accompanied by impaired annexin A6 translocation after sarcolemmal disruption. Am J Pathol 2016, 186: $1610-1622$

17. Taniguchi M, Kurahashi H, Noguchi S, Sese J, Okinaga T, Tsukahara T, Guicheney P, Ozono K, Nishino I, Morishita S, Toda T: Expression profiling of muscles from Fukuyama-type congenital muscular dystrophy and laminin-alpha 2 deficient congenital muscular dystrophy: is congenital muscular dystrophy a primary fibrotic disease? Biochem Biophys Res Commun 2006, 342:489-502

18. Nevo Y, Halevy O, Genin O, Moshe I, Turgeman T, Harel M, Biton E, Reif S, Pines M: Fibrosis inhibition and muscle histopathology improvement in laminin-alpha2-deficient mice. Muscle Nerve 2010, 42:218-229
19. Hinz B, Phan SH, Thannickal VJ, Prunotto M, Desmoulière A, Varga J, De Wever O, Mareel M, Gabbiani G: Recent developments in myofibroblast biology: paradigms for connective tissue remodeling. Am J Pathol 2012, 180:1340-1355

20. Zanotti S, Gibertini S, Mora M: Altered production of extra-cellular matrix components by muscle-derived Duchenne muscular dystrophy fibroblasts before and after TGF-beta1 treatment. Cell Tissue Res 2010, 339:397-410

21. Melone MA, Peluso G, Petillo O, Galderisi U, Cotrufo R: Defective growth in vitro of Duchenne muscular dystrophy myoblasts: the molecular and biochemical basis. J Cell Biochem 1999, 76: $118-132$

22. Cohn RD, van Erp C, Habashi JP, Soleimani AA, Klein EC, Lisi MT, Gamradt M, ap Rhys CM, Holm TM, Loeys BL, Ramirez F, Judge DP, Ward CW, Dietz HC: Angiotensin II type 1 receptor blockade attenuates TGF-beta-induced failure of muscle regeneration in multiple myopathic states. Nat Med 2007, 13:204-210

23. Pines M, Halevy O: Halofuginone and muscular dystrophy. Histol Histopathol 2011, 26:135-146

24. Pines M, Spector I: Halofuginone: the multifaceted molecule. Molecules 2015, 20:573-594

25. Okayama T, Kikuchi S, Ochiai T, Ikoma H, Kubota T, Ichikawa D, Fujiwara H, Okamoto K, Sakakura C, Sonoyama T, Kokuba Y, Doi Y, Tsukita S, Bissell DM, Otsuji E: Attenuated response to liver injury in moesin-deficient mice: impaired stellate cell migration and decreased fibrosis. Biochim Biophys Acta 2008, 1782:542-548

26. Takahashi E, Nagano O, Ishimoto T, Yae T, Suzuki Y, Shinoda T, Nakamura S, Niwa S, Ikeda S, Koga H, Tanihara H, Saya H: Tumor necrosis factor-alpha regulates transforming growth factor-betadependent epithelial-mesenchymal transition by promoting hyaluronan-CD44-moesin interaction. J Biol Chem 2010, 285: 4060-4073

27. Baeyens N, Latrache I, Yerna X, Noppe G, Horman S, Morel N: Redundant control of migration and adhesion by ERM proteins in vascular smooth muscle cells. Biochem Biophys Res Commun 2013, 441:579-585

28. Chen YX, Zhang W, Wang WM, Yu XL, Wang YM, Zhang MJ, Chen N: Role of moesin in renal fibrosis. PLoS One 2014, 9:e112936

29. Zhu HY, Ng J, Salleh SM, Aung TT, Htoon MH, Beuerman RW: Moesin expression in fibrosis in the mouse cornea after sterile mechanical trauma or infection. Cornea 2014, 33:973-980

30. Fehon RG, McClatchey AI, Bretscher A: Organizing the cell cortex: the role of ERM proteins. Nat Rev Mol Cell Biol 2010, 11:276-287

31. Pore D, Gupta N: Ezrin-radixin-moesin family proteins in the regulation of B cell immune response. Crit Rev Immunol 2015, 35:15-31

32. Bretscher A, Edwards K, Fehon RG: ERM proteins and merlin: integrators at the cell cortex. Nat Rev Mol Cell Biol 2002, 3:586-599

33. Arpin M, Chirivino D, Naba A, Zwaenepoel I: Emerging role for ERM proteins in cell adhesion and migration. Cell Adhes Migr 2011, 5:199-206

34. Baumgartner M, Sillman AL, Blackwood EM, Srivastava J, Madson N, Schilling JW, Wright JH, Barber DL: The Nck-interacting kinase phosphorylates ERM proteins for formation of lamellipodium by growth factors. Proc Natl Acad Sci U S A 2006, 103: 13391-13396

35. Pines M: Targeting TGF $\beta$ signaling to inhibit fibroblasts activation as a therapy for fibrosis and cancer. Expt Opin Drug Dis 2008, 3:11-20

36. Pines M: Halofuginone for fibrosis, regeneration and cancer in the gastrointestinal tract. World J Gastroenterol 2014, 20:14778-14786

37. Fromes Y, Bouyon S, Nagi S, Roussel V, Genin O, Levi O, Halevy O, Pines M: Inhibition of fibrosis and improving function of the myopathic hamster cardiac muscle by halofuginone. J Exp Clin Cardiol 2014, 20:2351-2383

38. Turgeman T, Hagai Y, Huebner K, Jassal DS, Anderson JE, Genin O, Nagler A, Halevy O, Pines M: Prevention of muscle fibrosis and improvement in muscle performance in the $\mathrm{mdx}$ mouse by halofuginone. Neuromuscul Disord 2008, 18:857-868 
39. Spector I, Zilberstein Y, Lavy A, Genin O, Barzilai-Tutsch H, Bodanovsky A, Halevy O, Pines M: The involvement of collagen triple helix repeat containing 1 in muscular dystrophies. Am J Pathol 2013, 182:905-916

40. Irizarry RA, Hobbs B, Collin F, Beazer-Barclay YD, Antonellis KJ, Scherf U, Speed TP: Exploration, normalization, and summaries of high density oligonucleotide array probe level data. Biostatistics 2004, 4:249-264

41. Roffe S, Hagai Y, Pines M, Halevy O: Halofuginone inhibits Smad3 phosphorylation via the PI3K/Akt and MAPK/ERK pathways in muscle cells: effect on myotube fusion. Exp Cell Res 2010, 316: 1061-1069

42. Capote J, Kramerova I, Martinez L, Vetrone S, Barton ER, Sweeney HL, Miceli MC, Spencer MJ: Osteopontin ablation ameliorates muscular dystrophy by shifting macrophages to a proregenerative phenotype. J Cell Biol 2016, 213:275-288

43. Contreras O, Rebolledo DL, Oyarzún JE, Olguín HC, Brandan E: Connective tissue cells expressing fibro/adipogenic progenitor markers increase under chronic damage: relevance in fibroblastmyofibroblast differentiation and skeletal muscle fibrosis. Cell Tissue Res 2016, 364:647-660

44. Seale P, Sabourin LA, Girgis-Gabardo A, Mansouri A, Gruss P, Rudnicki MA: Pax7 is required for the specification of myogenic satellite cells. Cell 2000, 102:777-786

45. Sun G, Haginoya K, Wu Y, Chiba Y, Nakanishi T, Onuma A, Sato Y, Takigawa M, Iinuma K, Tsuchiya S: Connective tissue growth factor is overexpressed in muscles of human muscular dystrophy. J Neurol Sci 2008, 267:48-56

46. Bodanovsky A, Guttman N, Barzilai-Tutsch H, Genin O, Levy O, Pines M, Halevy O: Halofuginone improves muscle-cell survival in muscular dystrophies. Biochim Biophys Acta 2014, 1843:1339-1347

47. Hornsey MA, Laval SH, Barresi R, Lochmüller H, Bushby K: Muscular dystrophy in dysferlin-deficient mouse models. Neuromuscul Disord 2013, 23:377-387

48. Wang J, Liu H, Chen B, Li Q, Huang X, Wang L, Guo X, Huang Q: RhoA/ROCK-dependent moesin phosphorylation regulates ageinduced endothelial cellular response. Cardiovasc Diabetol 2012, 11:7

49. Chakraborty PK, Zhang Y, Coomes AS, Kim WJ, Stupay R, Lynch LD, Atkinson T, Kim JI, Nie Z, Daaka Y: G protein-coupled receptor kinase GRK5 phosphorylates moesin and regulates metastasis in prostate cancer. Cancer Res 2014, 74:3489-3500

50. Pan YR, Tseng WS, Chang PW, Chen HC: Phosphorylation of moesin by Jun N-terminal kinase is important for podosome rosette formation in Src-transformed fibroblasts. J Cell Sci 2013, 126(Pt 24): $5670-5680$

51. Shin J, Tajrishi MM, Ogura Y, Kumar A: Wasting mechanisms in muscular dystrophy. Int J Biochem Cell Biol 2013, 45:2266-2279

52. Kharraz Y, Guerra J, Pessina P, Serrano AL, Muñoz-Cánoves P: Understanding the process of fibrosis in Duchenne muscular dystrophy. Biomed Res Int 2014, 2014:965631

53. Abdou AG, Sakr S, Elwahed MM, Eladly EK: Immunohistochemical assessment of ezrin and moesin in colorectal carcinoma. Ultrastruct Pathol 2016, 40:181-188

54. Estecha A, Sanchez-Martin L, Puig-Kroger A, Bartolomé RA, Teixidó J, Samaniego R, Sánchez-Mateos P: Moesin orchestrates cortical polarity of melanoma tumour cells to initiate 3D invasion. $\mathrm{J}$ Cell Sci 2009, 122:3492-3501

55. Tseng BS, Zhao P, Pattison JS, Gordon SE, Granchelli JA, Madsen RW, Folk LC, Hoffman EP, Booth FW: Regenerated mdx mouse skeletal muscle shows differential mRNA expression. J Appl Physiol 2002, 93:537-545
56. Porter JD, Merriam AP, Leahy P, Gong B, Feuerman J, Cheng G, Khanna S: Temporal gene expression profiling of dystrophin-deficient $(\mathrm{mdx})$ mouse diaphragm identifies conserved and muscle groupspecific mechanisms in the pathogenesis of muscular dystrophy. Hum Mol Genet 2004, 13:257-269

57. Chen YW, Zhao P, Borup R, Hoffman EP: Expression profiling in the muscular dystrophies: identification of novel aspects of molecular pathophysiology. J Cell Biol 2000, 151:1321-1336

58. Haslett JN, Sanoudou D, Kho AT, Bennett RR, Greenberg SA, Kohane IS, Beggs AH, Kunkel LM: Gene expression comparison of biopsies from Duchenne muscular dystrophy (DMD) and normal skeletal muscle. Proc Natl Acad Sci U S A 2002, 99:15000-15005

59. Cacciottolo M, Belcastro V, Laval S, Bushby K, di Bernardo D, Nigro V: Reverse engineering gene network identifies new dysferlininteracting proteins. J Biol Chem 2011, 286:5404-5413

60. Smith YE, Vellanki SH, Hopkins AM: Dynamic interplay between adhesion surfaces in carcinomas: cell-cell and cell-matrix crosstalk. World J Biol Chem 2016, 7:64-77

61. Ponuwei GA: A glimpse of the ERM proteins. J Biomed Sci 2016, 23:35

62. Ibrahim IA, Nakaya M, Kurose H: Ezrin, radixin, and moesin phosphorylation in NIH3T3 cells revealed angiotensin II type 1 receptor cell-type-dependent biased signaling. J Pharmacol Sci 2013, 122:1-9

63. Jeon S, Kim NH, Kim JY, Lee AY: Stem cell factor induces ERM proteins phosphorylation through PI3K activation to mediate melanocyte proliferation and migration. Pigment Cell Melanoma Res $2009,22: 77-85$

64. Moon Y, Kim JY, Kim WR, Kim HJ, Jang MJ, Nam Y, Kim K, Kim H, Sun W: Function of ezrin-radixin-moesin proteins in migration of subventricular zone-derived neuroblasts following traumatic brain injury. Stem Cells 2013, 31:1696-1705

65. Leroy C, Belkina NV, Long T, Deruy E, Dissous C, Shaw S, Tulasne D: Caspase cleavages of the lymphocyte-oriented kinase prevent ezrin, radixin, and moesin phosphorylation during apoptosis. J Biol Chem 2016, 291:10148-10161

66. Nadarajah VD, van Putten M, Chaouch A, Garrood P, Straub V, Lochmüller H, Ginjaar HB, Aartsma-Rus AM, van Ommen GJ, den Dunnen JT, 't Hoen PA: Serum matrix metalloproteinase-9 (MMP-9) as a biomarker for monitoring disease progression in Duchenne muscular dystrophy (DMD). Neuromuscul Disord 2011, 21:569-578

67. Hathout Y, Brody E, Clemens PR, Cripe L, DeLisle RK, Furlong P, Gordish-Dressman H, Hache L, Henricson E, Hoffman EP, Kobayashi YM, Lorts A, Mah JK, McDonald C, Mehler B, Nelson S, Nikrad M, Singer B, Steele F, Sterling D, Sweeney HL, Williams S, Gold L: Large-scale serum protein biomarker discovery in Duchenne muscular dystrophy. Proc Natl Acad Sci U S A 2015, 112: $7153-7158$

68. Holland A, Dowling $\mathrm{P}$, Meleady $\mathrm{P}$, Henry M, Zweyer M, Mundegar RR, Swandulla D, Ohlendieck K: Label-free mass spectrometric analysis of the $\mathrm{mdx}-4 \mathrm{cv}$ diaphragm identifies the matricellular protein periostin as a potential factor involved in dystrophinopathy-related fibrosis. Proteomics 2015, 15:2318-2331

69. Yuan Y, Zhang F, Wu J, Shao C, Gao Y: Urinary candidate biomarker discovery in a rat unilateral ureteral obstruction model. Sci Rep 2015, 5:9314

70. Takamatsu H, Espinoza JL, Lu X, Qi Z, Okawa K, Nakao S: Antimoesin antibodies in the serum of patients with aplastic anemia stimulate peripheral blood mononuclear cells to secrete TNF-alpha and IFN-gamma. J Immunol 2009, 182:703-710

71. Lin X, Liang Q, Lin L, Ding Q, Wang X, Wang Y: Identification of anti-moesin antibodies in the serums of patients with antiphospholipid syndrome. Thromb Res 2015, 135:867-872 